\title{
Correction to: Vertical and Horizontal Inequality in Ecuador: The Lack of Sustainability
}

\author{
Ivan Gachet $^{1} \cdot$ Diego F. Grijalva $^{2} \mathbb{D} \cdot$ Paúl A. Ponce $^{3} \cdot$ Damián Rodríguez $^{4}$
}

Published online: 12 March 2019

(C) UNU-WIDER 2019

\section{Correction to: Soc Indic Res}

https://doi.org/10.1007/s11205-017-1810-2

The article Vertical and Horizontal Inequality in Ecuador: The Lack of Sustainability, written Ivan Gachet, Diego F. Grijalva, Paúl A. Ponce and Damián Rodríguez, was originally published electronically on the publisher's internet portal (currently SpringerLink) on December 2017 without open access.

With the copyright holders decision to opt for Open Choice the copyright of the article changed on February 2019 to (C) UNU-WIDER 2019, and this book is licensed under the terms of the Creative Commons Attribution-NonCommercial-ShareAlike 3.0 IGO License (https://creativecommons.org/licenses/by-nc-sa/3.0/igo/), which permits any noncommercial use, sharing, adaptation, distribution, and reproduction in any medium or format, as long as you give appropriate credit to the UNU-WIDER, provide a link to the Creative Commons licence and indicate if changes were made. If you remix, transform, or build upon this book or a part thereof, you must distribute your contributions under the same licence as the original.

The original article can be found online at https://doi.org/10.1007/s11205-017-1810-2.

Diego F. Grijalva

dgrijalva@usfq.edu.ec

1 International Independent Consultant, Quito, Ecuador

2 USFQ Business School, School of Economics, and Instituto de Economía, Universidad San Francisco de Quito USFQ, Campus Cumbayá, Quito, Ecuador

3 Secretaría Nacional de Planificación y Desarrollo SENPLADES, Quito, Ecuador

4 Université Paris 1 Panthéon-Sorbonne, Paris, France 